Portland: C.C. Publications, 1984.

16 Hirano M. Clinical examination of voice. In: Arnold GE, Winckel F, Wyke BD, eds. Disorders of human communication 5. New York: Springer-Verlag, 1981.

17 Barlow SM, Cole KJ, Abbs JH. A new head-mounted lipjaw movement transduction system for the study of motor speech disorders. $₹$ Speech Hearing Res 1983;26: 283-8.

18 Smith A, Denny M. High frequency oscillations as indicators of neural control mechanisms in human respiration, mastication, and speech. $f$ Neurophysiol 1990;63: 745-58.

19 Bendat JS, Piersol AG. Random data: analysis and measure- ment procedures. 2nd edn. New York: Wiley, 1986.

20 Hirano M, Kakita Y. Cover-body theory of vocal fold vibration. In: Daniloff RG, ed. Speech science: recent advances. San Diego: College Hill, 1985:1-46.

21 Smith $A$, Denny $M$, Wood J. Instability in speech muscle systems in stuttering. In: Peters HFM, Hulstijn W, systems in stuttering. In: Peters HFM, Hulstijn W, Starkweather W, eds. Speech motor

22 Weber CM, Smith A. Autonomic correlates of stuttering and speech assessed in a range of experimental tasks. $\mathcal{F}$ Speech Hearing Res 1990;33:690-706.

23 Marsden CD, Owen DA. The effect of adrenaline on physiological tremor in man. $\mathcal{F}$ Physiol 1967;188:40-1.

\section{Samuel Johnson: victim of Gilles de la Tourette syndrome}

The well known tics, mannerisms, postures and verba repetitions displayed by Samuel Johnson the great scholar-lexicographer suggest that he was a victim of Gilles de la Tourette syndrome. ${ }^{1-3}$

Thomas Tyers" commenting on Johnson said "he was to the last a convulsionary ... His gestures, which were a degree of St Vitus' Dance, in the street attracted the notice of many".

Boswell 156 observed "Dr Johnson is often muttering pious ejaculations, when he appears to be talking to himself."

"He commonly held his head on one side towards his right shoulder, and shook it in a tremulous manner, moving his body backwards and forwards, and rubbing his left knee in the same direction, with the palm of his hand. In the intervals of articulating he made various sounds with his mouth, sometimes as if ruminating, sometimes giving a half-whistle, sometimes making his tongue play backwards from the roof of his mouth, as if clucking like a hen, and sometimes .... pronouncing quickly under his breath, 'too, too, too'."
“... he had another particularity . . . his anxious care to go in and out at a door or passage, by a certain number of steps from a certain point . . . I have on innumerable occasions, observed him suddenly stop, and then seem to count his steps with a deep earnestness; . ..."

J M S PEARCE

1 McHenry L. Samuel Johnson's tics and gesticulations. f Hist Med 1967;22:152-68.

2 Murray TJ. Dr Samuel Johnson's movement disorder. $B M \Im$ 1979;1:1610-4.

3 Pearce JMS. Doctor Samuel Johnson: "the Great Convulsionary" a victim of Gilles de la Tourette's syndrome. $¥ R$ Soc Med 1993 (in press)

4 Tyers Thomas. A Biographical sketch of Dr Samuel Johnson. Gentleman's magazine, December 1784 (reproduced In: Hill GB. Johnsonian Miscellanies). London: duced In: Hill GB. Johnso

5 Boswell James. The life of Samuel fohnson LLD. London: James Blackwood, 1791:135-6.

6 Boswell James. The journal of $a$ tour of the Hebrides with Samuel fohnson LLD. London 1785. London: Everyman, 1948:8. 